\section{US scientists want} analysts has produced an "alternative military policy" for the United States which, it says, would buy a "better and safer defence" at only $60 \%$ of the cost of the present policy.

The Boston study group outlines its new strategy to reduce military spending in a 350-page book. The Price of Defense, which is being published shortly after President Carter has sent Congress a budget request for 1980 for a $3 \%$ real increase in defence spending.

The group says that the study is meant to "stimulate broad and serious debate of overall American military needs and foreign policy"- $-\mathrm{a}$ debate which it claims has not taken place in the United States for many years.

Speaking at a press conference last week, Dr Martin Moore-Ede, professor of physiology at Harvard University, explained that the Boston group's proposed reduction of $40 \%$ - or $\$ 50$ billion a year-in American defence expenditure would cut out "inertia, obsolescence and temptation: the inertia accounts for the entrenchment of high military budgets during peacetime, the obsolescence we cut are the easily-targeted, expensive and vulnerable remnants of the technological past, and the temptation we remove is the excess weaponry and forces that this nation possesses."

More specifically, the study recommends eliminating all of the United States' one thousand land-based intercontinental ballistic missiles over five years, although it concedes that a hundred of the latest Minuteman III ICBMs might be retained longer "as a hedge." All strategic nuclear bombers would also be retired, perhaps over eight years, on the grounds that they are "vulnerable, expensive and obsolete."

The Boston group argues that the retention of 31 Poseidon submarines, each carrying a maximum of 16 missiles, would leave the US with a virtually invulnerable nuclear deterrent sufficient to "wreck every Soviet and allied city and industrial district, plus many extra military targets". It sees no need for the new series of Trident submarines, the first two of which are under construction, and proposes cancelling them.

The Department of Defense's research and development activities would be severely pruned. The Pentagon would be left with only $\$ 100$ million a year to spend on basic research: the group proposes to transfer the remaining $\$ 300$ million to a new national technology foundation to "stimulate $\mathbf{R} \& \mathrm{D}$ in areas of expensive high technology where private industry is not yet willing to undertake the work". Applied research and development would be cut by two thirds.

The Boston group analysed the social effects of transferring $\$ 50$ billion from the military to the civilian sector of the economy, and estimates that the net effect would be a gain of two million jobs "because defense dollars create far fewer jobs than monies spent in other sectors of the economy."

Clive Cookson

The Price of Defense. Times Books, New York, at \$15.00. Clive Cookson is with The Times Higher Education Supplement.

\title{
UNCSTD meeting split on transfer of technology
}

Despite considerable opposition, the transfer of technology to developing countries will occupy a prominent, if controversial, position on the agenda of the United Nations Conference on Science and Technology for Development, in Vienna next August.

This emerged from the third meeting of UNCSTD's preparatory committee, which ended in New York on Monday, and at which delegates from a number of developed countries-in particular the United Kingdom, the US and West Germany-had argued that the issues involved were already being adequately debated in other forums.

In an address to the meeting, for example the British delegate, Dr Dennis Osborne said that attempts to duplicate negotiations on a code of conduct for the transfer of technology already underway elsewhere in the UN system "would lead to confusion and delay in reaching agreement".

Many of the recommendations in the UNCSTD secretariat's preliminary draft programme of action on this topic were "unacceptable to my government in their present form," Dr Osborne said However Mr Frank Joao da Costa, Secretary General of the conference, told the preparatory committee that the proposed agenda for Vienna and the draft programme merely reflected the wishes expressed by member countries-and that since the transfer of technology was high among the concerns of many developing countries in their national and regional papers, it would have to be addressed by the conference.

In its closing plenary session on Monday morning, postponed from last Friday to allow additional time for discussion, the committee accepted a resolution submitted by the Tunisian delegate on behalf of the Group of 77 to restructure the draft programmes of action under three 'target areas' : reinforcement of the scientific and technological capacities of developing countries; restructuring the conditions of access to scientific and technological

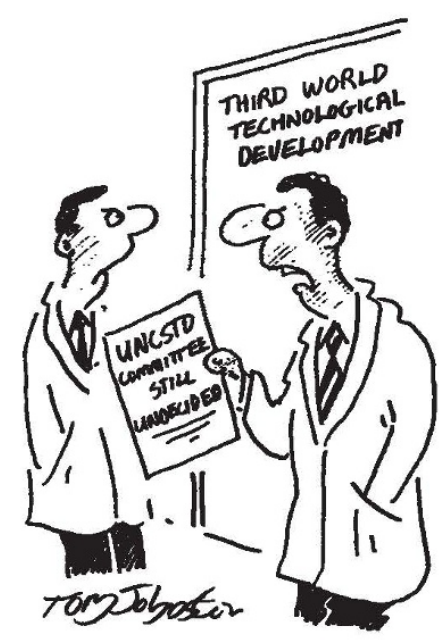

"If they delay long enough, the technology they give us will be out of date" knowledge as an integral part of the new international economic order; and better coordination of the scientific and technological activities undertaken within the UN system.

Despite agreement on the formal changes which they wish to see in the programmes of action, however, the Group of 77, which had established a working party during the committee meeting, were unable to come to any agreement on the substantive issues which the preliminary draft of the programme has raised.

Members of the group, to which over 120 developing countries now belong, have therefore agreed to hold a further meeting before the next preparatory committee meeting, which takes place in May, and to create a mechanism for continuing discussion of the issues up to UNCSTD itself.

According to some observers, it was this strategy on the part of the developing countries which led to the relative success of last year's UN conference on technological cooperation between developing countries. "If this is the case, then the game will have been worth a candle" one of them said.

Delegates at the meeting were unable to agree on whether there should be a fifth meeting of the preparatory committee before UNCSTD, although if such a meeting is called 26 June6 July has been put aside for it in New York.

David Dickson 